\author{
M.M. SAGADIYEVA', Zh.M. ZHUMANBAYEVA ${ }^{1}$
}

'Semey Medical University, Semey, the Republic of Kazakhstan

\title{
Difficulties experienced by parents of children with cancer: A literature review
}

Relevance: Children with cancer experience certain difficulties and needs associated with pain, nutrition, weakness, infection, and hyperthermia. All these needs require satisfaction and support both from medical staff and the children's families. One of the most difficult aspects of being parents of a child diagnosed with cancer is to balance normal family life with the sick child's needs and treatment requirements. Cancer is a serious disease that creates many stress factors for family members. Families mostly feel that everything has changed in their lives with the cancer diagnosis and have to make many adjustments, including financial spendings. Treatments, hospital visits, and hospitalizations suddenly invade their normal family life. A shock after diagnosis, painful therapy, an associated disruption of family and social development, and a constant uncertainty of relapse affect not only the sick child but also his/her family members.

The article aimed to describe the needs and difficulties of parents of a child with cancer.

Results: Data analysis revealed four main areas where the parents of children with cancer experience difficulties: 1. changes in the daily life of families caring for children with cancer, 2. financial challenges, 3. lack of knowledge, 4. pain management, and 5. psychological health.

Conclusion: Serious disease in a child possesses challenges for his/her parents due to the changes in families' daily lives. These parents need additional knowledge of care, psychosocial support, especially when making decisions they have to make, such as terminating cancer treatment, giving consent to refuse resuscitation or life support.

Keywords: family needs, caring for a child with cancer, living with a child with cancer, parental experience, pediatric palliative care, parental needs, nursing experience, childhood leukemia.

\section{Introduction}

Childhood cancer is a growing public health concern worldwide; it affects the lifestyle of children and their families. From the moment of diagnosis and throughout the entire disease to the terminal stage, cancer causes stress and impacts the patient's lifestyle and surroundings. In addition to the child's suffering, cancer affects the family, causing stress and lack of parents' readiness for home care, including pain management, providing medical services, and creating comfortable conditions. Cancer has a negative impact on various psychological and psychosocial aspects of the child's family. Family members may experience certain states of psychological distress and physical health problems [1].

\section{Materials and Methods}

A search for literary sources was conducted in PubMed and CINAHL databases, for dissertations - in the database of the National Scientific Portal of the Republic of Kazakhstan (http://www.nauka.kz). Individual works on the topic of research were also selected in library resources by manual selection.

Inclusion criteria: Russian and English full-text publications from 2005 to 2020 containing conclusions; articles with a high level of evidence (meta-analyses, systematic reviews, cohort studies); dissertations.

Exclusion criteria: articles published before 2000; publications with repeated data; incomplete articles; abstracts.

The keywords including 'life experience and child cancer,' 'experience of living with a child with cancer', and 'family needs in caring for a child with cancer' returned 188 articles in CINAHL and 111 articles in PubMed. Refining was necessary for a more manageable sample to be obtained, so further keywords such as 'childhood cancer' and 'difficulties of parents providing care' were added. This subsequently produced a more focused collection of papers, and, once culled, 77 papers were selected for critiquing. After additional processing and critical analysis of the articles, we included in the review 23 publications reflecting the difficulties and challenges families of children with cancer face.

\section{Results}

Changes in the daily life of families caring for children with cancer.

One of the main challenges for parents of children with cancer is balancing the child's treatment needs and normal family life. The normal way of life is replaced by visiting hospitals, medical examinations, and intensive therapy. Besides, one of the family members has to quit work to take care of the sick child. In turn, these problems can lead to a financial crisis, difficulties in family relations, and a decreased tolerance in the family [2].

Parents of children with incurable diseases often need a piece of advice on how to cope with a child's lack of appetite, inability to follow a drinking regime, and pain. They also need personal support with the difficulties they experience after diagnosis [3].

One of the experiences of parents of children diagnosed with cancer was a change in daily life due to the restrictions on certain leisure activities, a decrease in caring attitude towards themselves, increased financial expenses without social assistance, the presence of feelings of grief, sadness, fear, loneliness, and misery [4].

Home care is one of the most effective methods of treating children with cancer. However, this burden falls on the shoulders of parents. A study of the experience of parents of children with cancer showed that most of them changed their bed linen 1-2 times a week, aired the child's room, and

M.M. Sagadiyeva \M.M. Cazadueвa - (1) 0000-0002-4798-8760, e-mail: merei.sagadiyeva@nao-mus.kz

Zh.M. Zhumanbayeva \Ж.М. Жуманбаева - (1) 0000-0001-8941-862X, e-mail: zhanar.zhumanbayeva@nao-mus.kz 
kept the bedspreads and curtains clean to protect against infection during chemotherapy.

The age of mothers also has a certain significance in the provision of medical care. Mothers aged 35 and older explain that children's care and treatment take more time, and communication with other healthy children has a more positive context. This is because elder mothers have more experience providing care and establishing positive relationships with other children [1]. The negative side includes stressful relationships within the family, separation from the spouse and strained relationships, insufficient time for other family members [5].

Mothers are stressed by the need to be tougher towards their children and their spouses. The changes on the father's side include the need to quickly understand and focus on doing everything necessary to treat the disease. The art of caring for the family is a complex activity that requires hygiene, technical skills, and nursing training. Due to the severe diagnosis, mothers of children with cancer experience difficulties with insufficient support from medical staff, which is needed to ease the burden of care and increase family satisfaction [6].

Difficulties faced by families of children with cancer.

- Financial situation

The first difficulty for a family of a child with cancer is financial spendings.

Cancer treatment carries a financial burden on the entire family. The daily cost of treating childhood cancer is huge. This includes direct and indirect costs of treatment. New diagnostic and treatment methods are quite expensive, and these costs are borne by the family of the sick child, the health sector, and society as a whole. These expenses are classified as medical and non-medical expenses. Medical expenses include hospital expenses, diagnostic research expenses, and medication expenses. Non-medical expenses include expenses related to transportation, food, and accommodation. Costs incurred by families are called expenses out of pocket expenses. Because of the burden of cancer, sometimes parents may face reduced working hours or loss of work, resulting in a loss of income. Besides, self-employed parents sometimes have to close their businesses [7].

More in-depth research into the experience of parenting children with cancer showed that financial difficulties are among the important factors that impact the mental health status of parents of children with cancer. Families of children with cancer face additional expenses not covered by insurance and the healthcare system. Additional expenses lead to financial difficulties in the family. During this period, social assistance provided by friends, relatives, and their environment can reduce the development of depressive symptoms in parents. Protecting the financial stability of families of children with cancer has the potential to alleviate the psychological stress of both parents and their children [5].

- Lack of knowledge

The second difficulty for families of children with cancer is insufficient knowledge of parents about the existing disease.

During cancer treatment, such parents face various needs and difficulties since the disease affects various body systems, GIT problems being most common. Such children often experience malnutrition. Therefore, the parents must be informed about diet and nutrition, including the types of food the children should receive. Such children need to eat properly and receive the necessary nutrients. Parents need better nutrition education before, during, and after treatment. Families lack knowledge about the food interaction with medications and the dietary requirements of children with cancer especially at low white cell levels [8].
Parents of children with cancer actively participate in their children's care and treatment in hospitals and at home, where they face unfamiliar situations. After the diagnosis is established, parents feel insecure because they lack information about possible difficulties they will face after the treatment starts. Family members are afraid of new responsibilities they have never faced before. They note the need for clear and detailed information about their children's disease. The educational information provided at the first discharge after treatment helps better prepare for what they will experience at home; knowledge reduces stress and the frequency of re-admissions of children and adolescents [9].

\section{- Pain management}

Another important difficulty is managing the pain and symptoms of children with cancer at home. Pediatric cancer patients are at increased risk of relapsing pain throughout treatment, as treatment requires multiple painful procedures, and chemotherapy drugs can lead to iatrogenic pain. After switching from inpatient treatment to home care, parents of children with cancer have to combat pain. Parents tend to lower doses of analgesics, extend the time between administrations, and replace analgesics with non-medicinal methods such as massage, applying cold, etc. The use of pain medication by parents may be affected by socioeconomic factors. However, the main factor is the parents' beliefs about pain management and their impact on pain management at home. Parents need to communicate more with medical staff to assess pain in children properly. Determining the degree of pain and providing appropriate pain relief is necessary during home care and is complicated for family members. Therefore, there is a need for providing complete information about analgesia and training of parents and children in pain management [10].

If the child's family is responsible for pain management, parental involvement is an important element of caring for children with cancer [11]. A study found that parents regularly monitor and evaluate the localization and severity of pain experienced by their children, as the pain they feel affects their quality of life [12].

Family involvement based on the parents' experience can provide emotional and financial support to their children. On the other hand, mothers face some obstacles in taking care of their dying children. For example, in the absence of a nurse visiting a child at home to provide home care, mothers can not cope with their child's pain and might experience difficulties transporting their child to a hospital for pain management. Mothers try to do everything to please their children after a difficult experience related to treatment and medications. Parents feel depressed by their child's short life expectancy and exhaustion and continue trying to please them by providing everything the child wants. Some parents try to take care of their children by doing whatever they want; they always stay close, observe, entertain and support their children. Mothers leave their jobs to take care of the children; some close their businesses to focus on their sick children and ease their condition [13].

\section{- Psychological health situation}

A child's sickness always causes stress and changes the family's moods. When a child is diagnosed with an incurable disease, the parents' stress increases twofold. They look for the guilty, feel hostility and anger towards the whole world, and feel guilty themselves.

Besides, families are subjected to stresses at making decisions such as terminating treatment, giving consent to refuse resuscitation or life support. The parents suffer not only 
when they have to make such decisions but also long after that. Many of them struggle against it and experience regret [14]. Simultaneously, the uncertainty about the child's survival makes the parents suspend their life prospects [15]. Parents would choose chemotherapy or another treatment for their child, even if there is no real chance of a cure [16]. Unfortunately, children who receive end-stage cancer therapy suffer more than those who receive no treatment [17].

Moreover, at the end of life, parents experience both hope and hopelessness. Hope can ease the fear of losing a child and help maintain a harmonious relationship between parents and children. In some cases, when the child's condition worsens, hope can also help transit to a peaceful end of life [15]

Parents of children with life-limiting diseases constantly struggle for their child's life and face a very difficult reality [18].

All over the world, parents of children with cancer suffer during therapy and experience difficulties caring for their sick children at home. This can demand moving closer to a medical facility, receiving social support, and better awareness [19].

Anxiety and fear are at the heart of the complexities of caring for children with cancer. Parents may provide excessive care, which will negatively affect the child. One of the side effects of therapy for children with cancer is the development of fever, lack of appetite, vomiting, nausea, and difficulties with feeding. With the development of these conditions, parents have to prevent the development of infection and complications. Children's reactions to excessive care can be varied and interpreted as losing independence and influencing plans [20].

In modern healthcare, the widespread concept of "palliative care" covers a wide range of activities that improve the quality of life of seriously ill patients and their families. The goal of palliative care is to create conditions ensuring the patient's active life till the last days. In the Republic of Kazakhstan, such assistance is provided to all patients of all ages with an incurable disease. It addresses the spiritual, psychological, and social needs of each patient and their family [20,21].

Currently, the life experience of children with cancer and the dynamics of changes in the daily lives of families of children with cancer require deep and detailed study since there is not enough research in this area in our country. These studies must be of good quality. Currently, we could study the structure and the existing problems in palliative care provision in the Republic of Kazakhstan.

Palliative care aims to solve the problems of patients in the terminal stage of the disease, including children with cancer. No studies have been made in Kazakhstan of the difficulties and needs of parents of children with cancer, from the moment of diagnosis and for the entire disease period. In the context of the nursing care system reform in the Republic of Kazakhstan, qualitative research of parental care for children with cancer will promote nursing science development. There are data on statistics of childhood cancer and palliative care; however, the problems and needs of the parents raising children with cancer are no less important for the development of healthcare science.

\section{Conclusion}

The research has shown that parents of children with cancer face a whole set of difficulties and care needs, from the moment of diagnosis to the critical moment of the disease. The article reflects only the general aspects of problems the parents run into when they raise and take care of children with cancer. Studying the opinions and difficulties of parents of children with cancer is relevant and very important to improve the organization and provision of medical services at the appropriate level, to mitigate and ensure the quality of life of the child and all members of his/her family. Literature shows that parents of children with cancer experience changes in normal life routine, shock after diagnosis and certain financial difficulties, changes in daily routine, problems of pain management, psychological and health status, and insufficient awareness about their children's current state and the disease itself. All this evidences the need to research this topic in the Republic of Kazakhstan and then develop guidelines and standards for providing healthcare and nursing assistance to such families. Patient and family care, training, family counseling, and prevention are the direct duties of nursing staff.

\section{References}

1. Kahriman I., Canan Demirbag B., Kobya B.H. An Evaluation of the Changes Experienced by the Parents of Children with Cancer // Int. J. Caring Sci. - 2020. - №13(1). - P. 448-456;

2. Ak B., In Conk Z., Basbakal Z., Bal Y.H., Bolisik B. Nursing Approach to Children with Chronic and Life-Threatening. Fatal Disease // In: Pediatric Nursing. - Ankara: Academician Medicine Bookstore, 2013. - P. 917, 921.

3. Beser N., Oz F. Assessment of Depression and Qualıty of Life in Cancer Patients Receiving Chemotherapy// J. Cumhuriyet Univ. Sch. Nurs. - 2003. - №7. - P. 47-58;

4. Yesil T., Cetinkaya U.E., Korkmaz M. Examining the Life Quality and Care Burden of Those Who are Looking After the Patients Suffering from Chronıc Diseases // J. Health Sci. - 2016. - №5(4). P. 54-66;

5. Creswell P.D., Wisk L.E., Litzelman K., Allchin A., Witt W. P. Parental depressive symptoms and childhood cancer: the importance of financial difficulties // Support. Care Cancer. - 2014. - №22(2). - P. 503-511;

6. Neil L., Clarke S. Learning to live with childhood cancer: a literature review of the parental perspective // Int. J. Palliat. Nurs. 2010. - №16(3). - P.110-119;

7. Parsons S.K., Cohen J.T., Lichte M.L. Economic issues in pediatric cancer // In: Principles and practice of pediatric oncology / eds. Pizzo P.A., Poplack D.G. $-6^{\text {th }}$ edn. - Wolters Kluwer Lippincott Williams and Wilkins, Philadelphia, 2011. - P. 1428-1440;

8. Arpaci T., Toruner E.K., Altay N. Assessment of Nutritional Problems in Pediatric Patients with Cancer and the Information Needs of Their Parents: A Parental Perspective // Asia-Pac. J. Oncol. Nurs. - 2018. - №5(2). - P.231-236;

9. Machado Silva-Rodrigues F., Nascimento L., Kurashima A. Information for parents in pediatric oncology and nurses' educational interventions: integrative review // Revista de Enfermagem UFPE online. - 2016. - №10. - 2165. DOI: 10.5205/ reuol.9199-80250-1-SM1006201632;

10. Fortier M.A., Wahi A., Bruce C., Maurer Eva.L., Stevenson R. Pain management at home in children with cancer: a daily diary study // Pediatr. Blood Cancer. - 2014. - №61(6). - P. 1029-1033;

11. Palermo M., Karlson W. Developmental perspective family // Nat. Inst. Health. - 2015. - №69 (1). - P. 42-52;

12. Kiana B., Fatemeh A., Mostafa K. Effect of mother's voice on postoperative pain pediatric in tonsillectomy surgery // J. Pediatr. Nurs. - 2016. - №3(5). - P. 1-7;

13. Mariyana R., Allenidekania A., Nurhaeni N. Parents' voice in managing the pain of children with cancer during palliative care // Ind. J. Palliat. Care. - 2018. - №24(2). - P. 156-161;

14. Woodgate R.L., Yanofsky R.A. Parents' experiences in decision making with childhood cancer clinical trials // Cancer Nurs. - 2010. №33(1). - P. 11-18. doi: 10.1097/NCC.0b013e3181b43389;

15. Kars M.C., Grypdonck M.F., van Delden J.M. Being a parent of a child with cancer throughout the end-of-life course // Oncol. Nurs. Forum. - 2011. - №38(4). - P. 260-271. doi: 10.1188/11.ONF. E260-E271;

16.Maurer S.H., Hinds P.S., Spunt S.L., Furman W.L., Kane J.R., Baker J.N. Decision making by parents of children with incurable cancer who opt for enrollment on a phase I trial compared 
with choosing a do not resuscitate/terminal care option // J. Clin. Oncol. - 2010. - №28(20). - P. 3292-3298. doi: 10.1200/ JCO.2009.26.6502;

17. Heath J.A., Clarke N.E., Donath S.M., McCarthy M., Anderson V.A., Wolfe J. Symptoms and suffering at the end of life in children with cancer: An Australian perspective // Med. J. Australia. - 2010. №192(2). - P. 71-75;

18. Wang S.-C., Wu L.-M., Yang Y.-M., Sheen J.-M. The experience of parents living with a child with cancer at the end of life // Europ. J. Cancer Care. - 2019. - №28(4). - P. 1;
19. Yildirim S.H., Yilmaz M., Ozsoy S., Kantar M., Çetingul N. Experiences of Parents With the Physical Care Needs at Home of Children With Cancer // Cancer Nurs. - 2013. - №36(5). - P. 385-393;

20. Kurmanova A.T., Estemesova K.A., Asanov A.M., Turabekova G.S., Fedina N.N. The basis for the success of palliative care //Modern aspects of palliative care and nursing: Mater. II Int. Sci. Pract. Conf. Karaganda, 2013. - P.97-98. ISBN 978-601-202-141-7;

21. Bužgová R., Páleníková A. Lived experience of parents of children with life-limiting and life-threatening disease // Centr. Europ. J. Nurs. Midwifery. - 2015. - №6(1). - P.209-217.

\section{ТҰЖЫРЫМ}

\section{М.М. Сағадиева ${ }^{1}$, Ж.М. Жұманбаева ${ }^{1}$}

${ }^{1}$ Семей медицина университеті, Семей, Қазақстан Республикасы

\section{Қатерлі ісікке шалдыққан балалардың ата-аналары кездесетін қиындықтар}

Өзектілігі: Қатерлі ісікке шалдыққан балалар - ауырсыну, тамақтану, әлсіздік, инфекция және гипертермиямен байланысты белгілі бір қиындықтар мен қажеттіліктерді сезінеді. Осы қажеттіліктердің барлығы медициналық қызметкерлер тарапынан да, баланын жанұясы тарапынан да қанағаттандыру мен қолдауды талап етеді. Қатерлі ісік диагнозы қойылған бала ата-анасының өміріндегі ең қиын аспектілердің бірі - қалыпты отбасылық өмірді науқас баланың қажеттіліктері мен емдеу талаптарымен теңестіру. Қатерлі ісік - бұл отбасы мүшелеріне көптеген күйзеліс факторларын тудыратын ауыр сырқат. Қатерлі ісік диагнозы қойылған отбасылардың көпшілігі күнделікті өмір сүру қағидалары өзгерді деп санайды және қаржылық шығындарды қоса алғанда, көптеген түзетулер енгізуіміз керек деп ойлайды. Олардың қалыпты отбасылық өміріне ем алу, ауруханаларға бару және ауруханаға жатқызу жағдайлары кенеттен енеді. Диагноздан кейінгі соққы, отбасылық және әлеуметтік дамудың бұзылуы, рецидивтің тұрақты белгісіздігі науқас балаға ғана емес, оның отбасы мүшелеріне де әсер етеді.

Мақаланың мақсаты: қатерлі ісікке шалдыққан баланың ата-анасының қажеттіліктері мен қиындықтарын сипаттау.

Нәтижелері: Мәліметтерді талдау қатерлі ісігі бар балалардың ата-аналары күресетін төрт негізгі бағытmы анықтады: 1. Онкологиялық сырқатқа шалдыққан балаларды күтетін отбасылардың күнделікті өміріндегі өзгерістер; 2. Қаржылық жағдайдың мәселелері; 3. Білімнің жетіспеушілігі; 4. Ауырсынуды басқару жағдайы; 5. Психологиялық денсаулық жағдайb.

Қорытынды: Отбасының күнделікті өміріндегі өзгерістерге байланысты бала бойындағы сырқат ата-ана үшін қиын өмірлік жағдай. Осы ауыр кезеңде, әсіресе онкологиялық сырқаты бар балалардың ата-аналары қатерлі ісік ауруын емдеуді тоқтату, реанимациядан немесе өмірді қамтамасыз етуден бас тарту туралы шешімдер қабылдауға бағытталған жағдайларда, қатерлі ісікке шалдыққан балаға күтім жасау туралы білімге, психоәлеуметтік қолдауға мұқтаж болады,

Түйінді сөздер: отбасылық қажеттіліктер, қатерлі ісікке шалдыққан балаға күтім жасау, қатерлі ісікке шалдыққан баламен өмір сүру, ата-ана тәжірибесі, педиатриялық паллиативтік көмек, ата-ана қажеттіліктері, мейірбике ісі тәжірибесі, балалық лейкемия.

\section{АННОТАЦИЯ}

\section{М.М. Сагадиева ${ }^{1}$ Ж.М. Жуманбаева ${ }^{1}$}

${ }^{1}$ НАО «Медицинский Университет Семей», Семей, Республика Казахстан

\section{Трудности, с которыми сталкиваются родители детей, больных раком}

Актуальность: Дети с раком испытывают определенные трудности и потребности, связанные с болью, питанием, слабостью, инфекцией и гипертермией. Все эти потребности требуют удовлетворения и поддержки как со стороны медииинского персонала, так и со стороны семей детей. Один из самых сложных аспектов жизни родителей ребенка, у которого диагностирован рак, заключается в том, чтобы сбалансировать нормальную семейную жизнь с потребностями больного ребенка и требованиями к лечению. Рак - это серьезное заболевание, которое создает множество стрессовых факторов для членов семьи. Семьи в основном чувствуют, что все изменилось в их жизни с установлением онкологического диагноза, и им приходиться вносить много корректив, включая финансовые расходы. Лечение, посеще ние больниц и госпитализация внезапно вторгаются в их нормальную семейную жизнь. Шок после постановки диа гноза, болезненная терапия, связанное с этим нарушение семейного и социального развития, постоянная неопределенность рецидива влияют не только на больного ребенка, но и на членов его семьи.

Цель статьи: описание потребностей и трудностей, скоторыми сталкиваются родители ребенка, больного раком.

Результаты: Анализ данных выявил четыре основные области, в которых родители детей, больных раком, испытывают трудности:1. изменения в повседневной жизни семей, ухаживающих за детьми с онкологическими заболеваниями, 2. проблемы финансового характера, 3. недостаток знаний, 4. ситуачия управления болью и 5. ситуация психологического здоровья.

Заключение: Тяжелое заболевание у ребенка - это сложная жизненная ситуация для родителей, связанная с изменениями повседневной жизни семьи. Такие родители нуждаются в дополнительных знаниях по уходу, психосочиальной поддержке, особенно в ситуациях, направленных на принятие решений, которые им приходится принимать, таких как прекращение лечения рака, согласие на отказ от реанимации или жизнеобеспечения.

Ключевые слова: семейные потребности, уход за ребенком с раком, жизнь с ребенком с раком, родительский опыт, педиатрическая паллиативная помощь, потребности родителей, опыт сестринского ухода, детская лейкемия. 